\title{
UPAYA MENCEGAH HILANGNYA WAYANG KULIT SEBAGAI EKSPRESI BUDAYA WARISAN BUDAYA BANGSA
}

\author{
Mari Kusbiyanto ${ }^{1}$
}

\begin{abstract}
Puppet as cultural heritage can be destroyed if no awards are pretty good of society and the government against the perpetrators of the puppet art. Performers puppet puppeteer particularly as related rights owners of the staging puppet needs to obtain assurance economic acquired rights when the show was broadcast in the electronic media so that they can still earn enough income even though the show schedule is reduced as a result of the development of electronic media and telecommunications
\end{abstract}

Keywords: puppet, protection, puppeteer

\begin{abstract}
Abstrak
Wayang sebagai warisan budaya dapat musnah jika tidak ada penghargaan yang cukup baik dari masyarakat dan pemerintah terhadap pelaku seni wayang. Dalang sebagai pemain utama dalam wayang sebagai pemilik hak terkait di pementasan wayang perlu mendapatkan jaminan perlindungan hak ekonomi ketika acara itu disiarkan di media elektronik sehingga mereka masih bisa mendapatkan pendapatan yang cukup meskipun jadwal acara berkurang sebagai hasil dari pengembangan media elektronik dan telekomunikasi
\end{abstract}

Kata kunci: wayang, perlindungan, dalang

\section{Pendahuluan}

Sebuah peningalan budaya dapat tumbuh dan berkembang apabila ada pelaku yang terus berkarya, ada kelompok masyarakat yang mencintai budaya dan ada pemerintah yang melindungi dan memberikan fasilitas terselengaranya pementasan budaya tersebut. Wayang kulit sebagai peninggalan budaya juga memerlukan ketiga faktor tersebut untuk dapat terus tumbuh di masyarakat. Seni budaya wayang yang pada masa awal perkembangannya berjumlah cukup banyak hingga ratusan jenis saat ini tinggal berjumlah 25 yang masih ada di masyarakat. Musnahnya seni budaya wayang tersebut disebabkan karena tidak adanya pelaku yang memainkan pertunjukan di masyarakat.

Pelaku seni memainkan peran yang sangat vital dalam keberadaan budaya wayang kulit sehingga apabila pelaku seni tidak mendapatkan hasil

\footnotetext{
1 Penulis adalah Advokat pada Kusbiyanto \& Co Law Office, Jakarta. Alamat kontak: marikus76@gmail.com.
} 
yang cukup untuk membiayai kebutuhan hidupnya dia akan meningalkan profesinya tersebut.

Keberadaan wayang tidak bisa dilepaskan dari tokoh sentral dari sebuah pertunjukan wayang yaitu Dalang. Dalang adalah seseorang yang memainkan wayang dan bertugas sebagai pemimpin pertunjukan. Dalang yang terkenal antara lain Alm. Ki Nartosabdo, Ki Anom Surata, Ki Manteb Sudarsono, Ki Entus Susmana, Ki Purba Asmara, Alm Ki Hadi Sugita, Alm Ki Timbul Hadiprayitna, Ki Gina Purwacarita. Masing-masing dalang tersebut mempunyai ciri khas dalam memainkan wayang yang membuat masyarakat menyukai setiap pertunjukan wayang yang dilakukannya. ${ }^{2}$

Untuk setiap pertunjukan yang dilakukan, Dalang mempunyai hak yang dilindungi oleh HaKI yaitu hak terkait yang memungkinkan Dalang mendapatkan manfaat ekonomi atas setiap penayangan pertunjukannya di media baik radio,televisi maupun internet. Sebelumnya Dalang hanya mendapatkan manfaat ekonomi hanya dari setiap pertunjukan yang diselengarakannya yang hanya sekali didapat yaitu pada saat pertunjukan saja. Hadirnya undang-undang hak cipta nomor 28 Tahun 2014 memberikan hak pada dalang maupun pememegang hak terkait untuk mendapatkan manfaat ekonomi bukan hanya pada saat pagelaran namun juga pada saat pagelaran tersebut disiarkan oleh media baik secara langsung maupun tidak langsung yaitu berupa royalti yang dapat dinikmati oleh bukan hanya dirinya namun juga ahli warisnya.

Adanya royalti akan mendorong dalang dan penerusnya untuk terus berkarya sehingga wayang akan terus ada dan berkembang dari masa kemasa karena masalah utama musnahnya wayang adalah karena sedikitnya manfaat ekonomi yang diperoleh oleh pelaku wayang.

\section{Kaderisasi Dalang dan Perkembangan Pementasan Wayang Kulit di wilayah Jawa}

Indonesia kaya akan berbagai jensi wayang, menurut laporan Sekretarian Pewayangan Indonesia (SENAWANGI) terdapat 100 jenis wayang yang tersebur di Nusantara. Namun demikian hingga sekarang jenis wayang yang masih hidup dan bertahan di tengah-tengah masyarakat dapat dihitung dengan jari, antara lain seperti wayang kulit purwa, wayang golek Sunda, wayang Sasak (NTB), wayang Bali, wayang golek Jawa, wayang Jawa Timur. Jenisjenis wayang lain sudah jarang dipentaskan, bahkan menuju kepunahan, seperti wayang madya, wayang gedog, wayang klitik, wayang beber dan sebagainya. ${ }^{3}$

Kehidupan wayang kulit purwa Jawa sebelum Indonesia merdeka khususnya diwilayan surakarta mendapat pembinaan dari keraton, hal itu

\footnotetext{
${ }^{2}$ Ferdi Arifin, Wayang Kulit sebagai media pendidikan Budi Pekerti, "Jurnal Sejarah dan Budaya", (Jantra), Vol. 8, No. 1, Juni 2013, hal. 75.

${ }^{3}$ Guritno, P., Wayang, "Kebudayaan Indonesia dan Pancasila", (Jakarta: Universitas Indonesia Press, 1988), hal. 48.
} 
ditanai dengan berdirinya pendidikan dalan yang disebut Pasinaon Dhalang Surakarta (Padhasuka), atas prakarsa Paku Buwana X (1983-1939) yang berdiri tahun 1923. Berkat lulusan Padhasuka maka pedalangan gaya keraton atau Surakarta dapat disebarluaskan oleh aluminya antara lain seperti Pujasumarta, yang lulus dari Padhasuka tahun 1933, yang dalam pementasannya sangat menghormati kaidah-kaidah pedalangan gaya keraton, sehingga membawa dampak terhadsap dalang-dalang yang lain dan menyebar keseluruh wilayah Jawa Tengah dan Jawa Timur.

Demikian pula Pura Mangkunegaran di bawah kepemimpinan Mangkunegara VII mendirikan pendidikan dalang yang dinamai Pasinaon Dhalang Mangkunegaran (PDMN) pada tahun 1931, yang melahirkan dalang tenar seperty Wignyasutarna yang menyebarluaskan gaya Mangkunegaran ke wilayan Jawa Tengah dan Jawa Timur.

Kedua dalang tersebut (Pujasumarta dan Wignyasutarna) menjadi dalang yang paling populer dan disenangi masyarakat pada waktu itu (1940-1960), bahkan menjadi dalang kesayangan Presiden Republik Indonesia yang pertama yaitu Ir. Soekarno. Selanjutnya diikuti dalang-dalang lain yang juga mengembangkan dan menyebarluaskan pakeliran gaya Surakarta ke masyarakat pendukung pewayangan seperti : Nyatacarita, Arjacarita, Warsina, Panut Darmoko.

Dengan demikian pedalangan wayang kulit purwa gaya Surakarta berkembang luas berkat para lulusan Padhasuka dan PDMN, bahkan menjadi panutan dan kiblat para dalang-dalang pemula maupun para dalang yang berada di luar Surakarta. Di keraton Yogyakarta juga mendirikan pendidikan formal dalang yang dinamai Hambiwarakake Rancangan Andhalang disingkat Habhirandha, yang didirikan atas prakarsa Hamengkubuwana VIII (19121939), yang berdiri tahun 1925. Lulusan Habhirandha yang menjadi dalang tenar dan diterima oleh masyarakat antara lain Timbul Hadiprayitno.

Dalang Timbul yang menyebarluaskan gaya pakeliran keraton Yogyakarta atau gaya Mataraman ke seluruh Jawa Tengah, DIY, dan di wilayah Daerah Khusus Ibukota (Jakarta). Kemudian disusul dalang - dalang lain seperti Suparman, Hadi Sugita dan lain-lainnya. Dengan demikian perkembangan wayang kulit purwa Jawa didominasi dua gaya, yaitu gaya Surakarta dan gaya Yogyakarta yang tersebar luas ke seluruh Nusantara bahkan ke mancanegara atau ke tingkat nasional maupun tingkat internasional.

Pada tahun 1950-1960 wayang kulit purwa Jawa baik gaya Surakarta dan Yogyakarta mengalami perkembangan yang luas baik secara kualitatif maupun secara kuantitatif, dan gaya keraton masih menjadi panutan para dalang pada umumnya.

Di samping wayang kulit, wayang golek Jawa juga hidup di tengah masyarakat terutama di daerah Sentolo Yogyakarta, Kebumen dan daerah pesisiran seperti di Tegal, Pekalongan. Disisi lain wayang madya dan wayang gedog masih sering dipentaskan terutama di keraton Surakarta dan di pura Mangkunegaran. Pada era itu dalang yang mendapat tempat di masyarakat dan 
sangat terkenal antara lain Pujasumarta dari Klaten, Nyatacarita dari Kartasura, Arjacarita, Wignyasutarna, Warsina Gunasukasna.

Kehidupan seni pertunjukan wayang di tengah masyarakat di samping menyertai reite de passages juga menyertai upacara seremonial seperti peresmian gedung baru, pembukaan jembatatan menyertai ritual desa (bersih desa, nyadranan, suran, sedekah laut, ruwatan) dan sebagainya. Kepopuleran para dalang tersebut di atas makin menurun setelah Nartasabda muncul pada tahun 1957/1958.

Dalang Nartasabda tampil dengan gaya pedalangan yang berbeda dengan kaidah pedalangan keraton walaupun ia menganut pakeliran gaya Surakarta, bahkan para guru-guru dalang yang diserap Nartasabda seperti Pujasumarta, Wignyasutarna, pakelirannya murni gaya keraton Surakarta dan gaya Mangkunegaran. Nartasabda meramu gaya pedalangan para dalang ternama seperti humornya meniru Nyatacarita, sabet menuri Arjacarita, sedangkan catur dan dramatik serta sanggit meniru Pujasumarta dan Wignyasutarna.

Kehadiran Nartasabda dalam jagad pedalangan memberi warna tersendiri pada wauju pakeliran wayang gaya pedalangan yang mencakup: janturan, genem, pocapan, banyol, gendhing-gendhing, sulukan dan sanggit berbeda dengan pakeliran pada umumnya.

Menurut Nartasabda pakelirannya disesuaikan dengan prekembanan zaman dan perubahan masyarakat, maka karya pakelirannya disebut pedhalangan gaya baru. Ia yang memadukan gaya pakeliran Surakarta dan gaya pakeliran Mataraman pertama kali, bahkan mencampur adukan gendhing wayangan Surakarta dengan gendhing wayangan Yogyakarta, sulukan, dhodogan dan keparakan gaya Mataraman terutama pada agegan gara-gara.

Garapan pakeliran Nartasabda menimbulkan barbagai komentar dari para pendukung pewayangan antara lain dikatakan bahwa, pembaharuan yang hebat dalam jagad pedalangan dirintis oleh Nartasabda, serta ia mumlai gaya lucu untuk narasi bahkan dari awal pertunjukan atau jejer sudah mamasukan humor.

Walaupun gaya pedalangannya menimbulkan pro dan kontra di kalangan para pendukung wayang, tetapi ia mendapat sambutan di tengah-tengah masyarakat, bahkan gaya pedalangannya sebagai kiblat para dalang yunior dan para dalang generasi penerus.

Pada tahun 1960 sampai dengan tahun 1986 Nartasabda berada di puncak ketenarannya yang membuat kehidupan jagad pewayangan lebih semarak dan berkembang, terutama wayang kulit yang mengambil cerita Mahabarata. Jagad pedalangan pada waktu itu tidak hanya menggarap masalah esensi lakon atau masalah kejiwaan saja, tetapi pedalangan juga dititipi pesan-pesan dari pemerintah terutama yang menyangkut kebijakan pemerintah atau pesan-pesan yang berupa propaganda untuk kepentingan golongan tertentu. Maka dunia pewayangan semakin semarak dan hidup subur di tengah masyarakat pendukung wayang, tidak hanya sebagai hiburan rohani tetapi juga sebagai media hiburan, penerangan, alat propaganda, pendidikan dan juga alat dakwah.

Bentuk wayang yang lain seperti wayang golek Jawa, wayang madya, wayang gedog, wayang klitik semakin tersisih dari tengah-tengah masyarakat oleh karena wayang-wayang itu tidak fleksibel seperti wayang kulit purwa. Di 
samping itu jeis-jenis wayang itu kurang dikenal oleh masyarakat bahkan sumber ceritanya kurang dipahami oleh pendukung wayang, karena wayang madya mengambil cerita dari Serat Pustaka Raja Purwa, wayang gedog ceritanya mengambil dari cerita Panji; dan wayang Golek jawa ceritanya mengambil dari Serat Menak; wayang krucil mengambil dari Serat Damarwulan, sedangkan wayang kulit ceritanya mengambil dari Mahabarat atau Ramayana yang tokoh-tokohnya sangat akrab dan dikenal dimengerti oleh masyarakat luas pendukung wayang, terutama tokoh-tokoh Pandawa dan Korawa.

Pada tahun 1990, pertunjukan wayang kulit mengalami perubahan yang mendasar, yaiut munculnya garapan wayang yang disajikan oleh dua sampai tiga dalang atau wayang layar panjang yang menyajikan satu lakon tetapi dilakukan oleh tiga orang dalang. Posisi para swarawati atau pesindhen duduk di tengah-tengah selanya layar atau kelir, dan instrumen gamelan yang untuk mengiringi tidak hanya gamelan slendro dan pelog, tetapi ditambah instrumen non gamelan seperti drum, keyboard, dan lain sebagainya. Demikian pula ditambah penyanyi dan pelawak yang ikut dalam pertunjukan wayang bahkan para penari.

Pertunjuka wayang seperti ini dipelopori oleh Ganasidi (Lembaga pembina seni pedalangan Jawa Tengah) yang dinamakan wayang pantap. Dengan demikian perkembangan wayang kulit di Jawa semakin semarak dan rame terutama untuk fungsi yang bersifat hedonistik atau hiburan sesaat. Garapan pakeliran seperti ini tampaknya terus berlanjut bahkan terus diikuti oleh para dalang yunior, bahkan menjadi model pertunjukan wayang dewasa ini. Setiap pertunjukan wayang di daerah maupun di kota yang dilakukan oleh dalang yang sudah laku atau baru pemula selalu menggunakan musik non gamelan, memasukan pelawan dan penyanyi, bahkan musik campur sari juga masuk dalam pertunjukan wayang. ${ }^{4}$

Pada waktu seni pertunjukan wayang didukung oleh raja atau penguasa (government support), terbentuk tradisi pedalangan gaya keraton yang dikukuhkan dalam pendidikan formal dalang seperti Padhasuka dan Habirandha seperti Padhasuka dan Habirandha. Seiring dengan perubahan sosial yang terjadi bahwa, pertunjukan wayang dewasa ini didukung oleh masyarakat (communal support), artinya masyarakat yang menghidupi dan menanggap wayang untuk berbagai kepentingan seperti menyertai perkawinan, khitanan, ulang tahun, syukuran dan sebagainya. Dengan demikian pedalangan yang didukung oleh masyarakat akan melahirkan gaya pedalangan yang baru yang sesuai dengan selera masyarakat. Hal itu juga dikatakan oleh Arnold Hauser dalam bukunya The Sociology of Art (1974), yang menyatakan bahwa, seni merupakan produk masyarakat maka pandangan masyarakat tertentu akan mempengaruhi wujud seni yang dihasilkan oleh masyarakat itu. Bertolak dari pemikiran Hauser, maka pertunjukan wayang kulit purwa Jawa juga

\footnotetext{
${ }^{4}$ Hasrinuksmo B., "Ensiklopedi Wayang Indonesia”, (Jakarta: Sena Wangi, 1999), hal. 64.
} 
mengalami perubahan baik dari teknis pakelirannya, maupun tanggapan penonton terhadap ertunjukan wayang. Hal ini terjadi karean wayang merupakan bagian dari kebudayaan tidak luput dari pengaruh kebudayaan modern, dan tidak jarang bentuk-bentuk kesenian termasuk wayang diciptakan untuk kebutuhah praktis dan mengikuti selera pasar serta kurang memperhatikan nilai estetis.

Fenomena yang terjadi dalam jagad pedalangan sekaran ini mengisyaratkan adanya pergeseran cara pandang masyarakat baik para pelaku wayang (dalang), maupun penonton dalam menyikapi pertunjukan wayang. Bentuk pakeliran wayang dewasa ini yang dikemas untuk kepentingan massa, harus menyesuaikan dengan selera penonton yang telah mengalami perubahan, karean pertunjukan wayang merupakan akulturasi antara selera estetis penonton dengan selera estetis dalang. Dampak dari pergeseran pertunjukan wayang dewasa ini, maka terjadi kekaburan nilai-nilai, nilai lama telah ditinggalkan, sedangkan nilai-nilai baru belum mantap fungsinya bahkan belum ditemukan, hal itu tercermin dalam setiap pertunjukan wayang kulit masa kini. Berdasarkan pengamatan di lapangan bahwa sajian pakeliran wayang dewasa ini ada kecenderungan makin berkembang menjadi bentukbentuk hiburan sebagai komoditi komersial. Dengan demikian pertunjukan wayang dewasa ini secara kuantitas masih menggembirakan, walaupun diterpa oleh arus modernisasi dan kemajuan teknologi, informasi dan komunikasi. Pakeliran wayang masih tetap eksis di tengah-tengah masyarakat pendukungnya walaupun dalam sajiannya aspek yang bebentuk sakral, magis dan simbolis serta kadnungan nilai artistik, nilai kultural dan nilai moral religius tampak semu.

Pertunjukan wayang kulit purwa tradisi baik gaya Surakarta maupun gaya Yogyakarta hingga sekarang masih segar, hidup di tengah masyarakat pendukung budaya Jawa oleh karena adanya fkator internal dan faktor eksternal. Faktor internal yang datang dari para senimannya atau para pelaku wayang selalu berusaha menyesuaikan diri dengan perubahan zaman, ia mencoba membuat garapan baru atau pengembangan wayang baru. Hal itu ditandai dengan munculnya bentuk-bentuk pertunjukan wayang, seperti bentuk pakeliran wayang padat, wayang layar lebar, wayang sandosa, wayang multimedia, wayang kemasan dan sebagainya. Hal itu di dukung dengan hadirnya pendidikan formal dalang yang berbentuk akademis seperti Institut Seni Indonesia yang memiliki program studi seni pedalangan. Sedangkan faktor eksternal yang datang dari para penonton atau pendukung wayang, mereka beranggapan bahwa pertunjukan wayang di dalamnya terkandung nilainilai historis, nilai filosofis, pedagogis dan niali simbolis. Bahkan mereka memandang bahwa pertunjukan wayang merupakan pandangan hidup masyarakat Jawa terutama lakon yang mengisahkan Pandawa dan Korawa. Sedangkan menurut peniliti asing B. Anderson bahwa mitologi wayang berkaitan dengan eksistensial orang Jawa. Bagai para politikus dan para pengambil kebijakan pemerintah bahwa pertunjukan wayang kulit merupakan media yang ampuh untuk menyebar luaskan ide-ide pembangunan, maupun untuk mempengaruhi aspirasi politik untuk golongan partai tertentu. 
Pertunjukan wayang ternyata juga mengalami perubahan menyesuaikan dengan kebutuhan masyarakat dari yang semula ketat akan aturan-aturan menjadi longar mengikuti trend yang ada agar disukai oleh masyarakat. Semua perubahan tersebut tidak lepas dari faktor ekonomi, bila pertunjukan disukai masyarakat maka banyak masyarakat akan melihat pertunjukan baik secara langsung dalam sebuah pagelaran wayang kulit maupun melalui media elektronik dan ketika pertunjukan banyak dilihat dan diliput dalang akan mendapatkan banyak penghasilan dari kegiatan pementasan dan peliputan tersebut.

\section{Pertunjukan Wayang Kulit}

Seni memainkan wayang yang biasa disebut pagelaran, merupakan kombinasi harmonis dari berbagai unsur kesenian. Pada pagelaran wayang kulit dituntut adanya kerjasama yang harmonis baik unsur benda mati maupun benda hidup (manusia). Unsur benda mati yang dimaksud adalah sarana dan alat yang digunakan dalam pagelaran wayang kulit. Sementara unsur benda hidup (manusia) adalah orang-orang yang berperan penuh dalam seni pagelaran wayang kulit.

\section{Unsur Benda}

Unsur benda yang ada dalam pagelaran wayang kulit adalah alat-alat yang berupa benda tertentu yang digunakan dalam pagelaran wayang tersebut. Bahkan terdapat unsur materi yang harus ada (karena tidak bisa digantikan). Unsur materi yang dimaksud antara lain: wayang yang terbuat dari kulit lembu, kelir, debog (batang pohon pisang), seperangkat gamelan, keprak, kepyak, kotak wayang, cempala, dan blencong. Seperangkat alat tersebut harus ada, karena alat-alat tersebut tidak bisa digantikan. Akan tetapi pada perkembangan zaman ada modifikasi atau pengubahan yang bibuat berdasar kebutuhan atau kreatifitas seniman, namun keberadaan wayang dan kelir tidak bisa ditinggalkan.

1) Wayang kulit Jawa tentunya terbuat dari kulit. Pada umumnya terbuat dari kulit sapi namun ada juga yang dibuat dari kulit kambing. Proses pembuatannya pun cukup lama, mulai dari direndam lalu di gosok terus dipentang supaya tidak kusut kemudia dibersihkan bulu-bulunya. Baru setelah itu diberi pula untuk kemudian ditatah sesuai dengan gambar pola, dan terakhrir diwarnai. Jadilah wayang hasil kreasi seni pahat dan seni lukis.

2) Gamelan adalah seperangkat alat musik perkusi dan petik serta gesek yang mengiringi pagelaran wayang. Jumlahnya sangat banyak. Macam gamelan antara lain bonang, gambang, gendang, gong, siter, kempul, dll. Gamelan dimainkan secara bersama- 
sama membentuk alunan musik yang biasa disebut gending. Inilah seni kreasi musik dalam pagelaran wayang.

3) Kelir adalah layar lebar yang digunakan pada pertunjukan wayang kulit. Pada rumah Joglo, kelir di pasang pada bagian 'pringgitan'. Bagian ini merupakan bagian peralihan dari pada ranah publik, pendopo dengan ranah privat, ndalem atau nggandok. Oleh karena itu penonton wayang kulit yang tergolong keluarga, pada umumnya nonton di bagian dalam ndalem, yang sering dianggep nonton mburi kelir. Nonton di belakang kelir ini memang benar-benar ,wewayangan', atau bayang-bayang. Lihat buku „Aspek Kebudayaan Jawa Dalam Pola Arsitektur Bangunan Domestik dan Publik' (Subanindyo, 2010). Dari sinilah pengaruh blencong yang seolah-olah „menghidupkan" wayang akan dapat terlihat (lihat: Blencong). Penonton juga tidak terganggu oleh adanya gamelan. Bagi penonton publik, mereka menonton didepan kelir, sehingga selain dapat melihat keindahan dari pada peraga wayang itu sendiri, oleh karena tatah dan sungging-nya, berikut simpingannya, juga dapat menyaksikan deretan pesinden atau waranggana manakala ada. Sayang, menyaksikan dari sisi ini selain tak dapat menyaksikan pengaruh blencong, dimana wayang seolah-olah menjadi hidup, juga terkadang terhalang oleh gamelan, terutama gayor untuk kempul dan gong.

4) Debog adalah batang pisang yang digunakan untuk menancapkan wayang (simpingan). Di simping artinmya dijajar. Baik yang dimainkan maupun yang yang dipamerkan (display), digunakan 'debog'. Barang tentu untuk "menancapkan" wayang yang di-display juga ada aturan-aturan tertentu. Mana wayang yang harus ada disebelah kanan ki dalang, mana pula yang harus berada disebelah kirinya. Tugas 'menyimping' ini sesungguhnya tidak terbatas hanya memasang wayang yang harus di-display, akan tetapi juga mempersiapkan segala sesuatu keperluan dalang. Misalnya menyediakan wayang-wayang yang akan digunakan (play) sesuai urutan adegannya, menempatkan kotak wayang berikut keprak dan kepyaknya, menyediakan cempala, memasang dan menyalakan maupun mengatur sumbu blencong, lampu minyak yang khas digunakan dalam pertunjukan wayang kulit, dan lain-lain. Sekali-sekali juga membantu pelayanan konsumsi (makan minum, rokok) untuk dalang. Untuk penyiapan ini terkadang dibantu oleh anak-anak muda sebagai salah satu media pendidikan untuk mengenali dan akhirnya mencintai wayang.

5) Blencong adalah lampu minyak (minyak kelapa - lenga klentik) yang khusus digunakan dalam pertunjukan wayang kulit. Design-nya juga khusus, dengan cucuk (paruh) dimana diujungnya akan menyala api sepanjang malam. Oleh karenanya 
seorang penyimping harus mewaspadai pula keadaan sumbu blencong tersebut manakala meredup, atau bahkan mati sama sekali. Tak boleh pula api itu berkobar terlampau besar. Karena akan mobat-mabit. Kalaupun lampu penerangan untuk dalang pada masa sekarang sudah menggunakan listrik, sesungguhnya ada fungsi dasar yang hilang atau dihilangkan dari penggunaan blencong tersebut. Oleh karena blencong adalah lampu minyak, maka apinya akan bergoyang manakala ada gerakan-gerakan wayang, lebih-lebih waktu perang, yang digerakkan oleh ki dalang. Ada kesan bahwa ayunan api (kumlebeting agni) dari blencong itu seolah-olah memberikan nafas dan atau menghidupkan wayang itu sendiri. Hal yang tak terjadi manakala penerangan menggunakan listrik atau tromak (petromax). Saat ini blencong sudah jarang digunakan. Dianggap kurang praktis dan merepotkan.

6) Kotak wayang berukuran 1,5 meter kali 2,5 meter ini akan merupakan peralatan dalang selain sebagaimana sudah diutarakan merupakan tempat menyimpan wayang, juga sebagai 'keprak', sekaligus tempat menggantungkan 'kepyak'. Dari kotak tempat menyimpan wayang ini juga akan dikeluarkan wayang, baik yang akan ditampilkan maupun yang akan disimping. Di-simping artinya dijajar, di-display di kanan dan kiri layar (kelir) yang ditancapkan di debog (batang pisang). Kotak akan ditaruh dekat dalang, di sebelah kiri, dan ditentang yang dekat dalang ditempatkan kepyak. Sedang kepraknya justru bagian dari kotak yang dipukul dengan cempala. Keprak adalah suara dhodhogan sebagai tanda, disebut sasmita, dengan jenis tertentu diwujudkan pemukulan pada kotak dengan menggunakan cempala. Sementara pada kepyak, berupa tiga atau empat lempengan logam (kuningan/gangsa atau besi) yang digantungkan pada kotak, juga dipukul dengan cempala, dalam bentuk tanda tertentu, juga sebagai sasmita atau tanda-tanda untuk - selain mengatur perubahan adegan - merubah, mempercepat, memperlambat, sirep, menghentikan atau mengganti lagu (gendhing). Terdengar nada yang berbeda antara kepyak wayang kulit Jogya dan gaya Surakarta.

7) Cempala merupakan piranti sekaligus 'senjata' bagi dalang untuk memberikan segala perintah, baik kepada wiraniyaga, wiraswara maupun waranggana. Bentuknya sangat artistik, bagaikan meru. Ia bisa dipukulkan pada kotak, sebagai keprak, bisa pula ke kepyak, tiga/empat lempengan logam yang digantungkan pada kotak wayang. Pada saat ke dua tangan dalang sedang memegang wayang - dan ini yang unik - maka tugas untuk membunyikan keprak maupun kepyak, dengan tetap menggunakan cempala, dilakukan oleh kaki kanan ki dalang. 
Cempala - dengan desain sedemikian rupa itu - akan dijepit di antara ibu jari dan jari telunjuk berikutnya. Menggunakan cempala memerlukan latihan untuk memperoleh tingkatan ketrampilan tertentu. Memukul kotak dengan cempala, Ki Dalang dapat memilih berbagai kemungkinan pembangun suasana dengan dhodhogan, seperti ada-ada, pathetan, kombangan. Dapat pula sebagai perintah kepada karawitan untuk mengawali, merubah, sirep, gesang atau menghentikan gamelan. Juga dapat digunakan untuk memberikan ilustrasi adegan, seperti suara kaki kuda, suara peperangan dan lain-lain. Artinya, ketika ke dua belah tangan ki dalang sedang memainkan wayang, maka keprak atau kepyak dapat juga berbunyi. Suatu keprigelan yang jarang dapat dilihat oleh para penonton wayang, karena biasanya ia sedang asyik mengikuti adegan yang ditampilkan di kelir (layar). Padahal untuk mencapai tingkat keprigelan tersebut, seorang dalang harus melakukan latihan-latihan yang intensif. Betapa tidak, keempat anggota badan, tangan dan kaki harus terus bergerak, sementara pikiran dan pandangan terfokus pada apa yang dilakukannya di layar/kelir.

\section{Unsur Manusia}

Dalang, penyimping, penabuh, dan sinden adalah orang-orang yang berperan penting dalam kelancaran dan keberhasilan sebuah pagelaran wayang. Mereka adalah orang-orang yang memiliki kemahiran khusus dalam bidangnya masing-masing. Berkat kemahiran khusus tersebut, terkadang mereka tidak bisa digantikan oleh sembarang orang.

1) Dalang adalah sutradara, pemain, artis, serta tokoh sentral dari pada suatu pertunjukan wayang. Tanpa dalang, maka pertunjukan wayang itu tidak ada. Apalagi untuk dalang pada pertunjukan wayang kulit. Komunikasi antara dalang dengan unit pendukung, perlengkapan dan peralatan pertunjukan wayang merupakan komunikasi yang unik. Melalui segenap indera yang dimilikinya, ia berkomunikasi dengan kompleksitas orang dan peralatan yang lazim digunakan dalam suatu pertunjukan wayang. Tanpa suatu skenario yang dipersiapkan terlebih dahulu, namun wayang tampil secara spontan, kompak dan tidak pernah mengalami 'out of order', semalam suntuk. Sungguh suatu bentuk teater yang "aneh" karena meskipun tanpa suatu skenario - padahal dalang dapat memilih beratus lakon atau cerita baku (babon-pakem), carangan, anggitan (sanggit) - tontonan dapat berjalan mulus dari jejeran sampai tancep kayon.

2) Penyimping adalah orang yang membantu dalang dalam menyiapkan wayang yang di jajar (disimping) pada debog 
(simpingan). Tugas 'menyimping' ini sesungguhnya tidak terbatas hanya memasang wayang yang harus di-display, akan tetapi juga mempersiapkan segala sesuatu keperluan dalang. Misalnya menyediakan wayang-wayang yang akan digunakan (play) sesuai urutan adegannya, menempatkan kotak wayang berikut keprak dan kepyaknya, menyediakan cempala, memasang dan menyalakan maupun mengatur sumbu blencong, lampu minyak yang khas digunakan dalam pertunjukan wayang kulit, dan lain-lain. Sekali-sekali juga membantu pelayanan konsumsi (makan minum, rokok) untuk dalang. Untuk penyiapan ini terkadang dibantu oleh anak-anak muda sebagai salah satu media pendidikan untuk mengenali dan akhirnya mencintai wayang.

3) Panjak adalah orang yang bertugas memainkan gamelan. Orang-orang yang bertugas sebagai penabuh gamelan harus mempunyai kemahiran khusus dalam memainkan lagu (gendhing) sesuai dengan permintaan si dalang. Permintaan si dalang tentunya tidak verbalistik, namun penabuh gamelan diharuskan memahami isi cerita/lakon wayang dan gendhing yang dimainkan hendaknya diselaraskan dengan lakon cerita wayang. Hal inilah menuntut ketajaman intuisi bagi penabuh gamelan dalam pagelaran wayang, karena dalam pagelaran wayang tidak disediakan notasi musik dalam memainkan gamelan. Semuanya menggunakan intuisi seniman.

4) Waranggana adalah penyanyi wanita dalam seni karawitan yang dimainkan dalam pagelaran wayang kulit. Lazim juga disebut pesinden. Penyanyi ini selain harus mempunyai kemahiran dalam menyanyi dengan suara yang merdu, namun juga ketahanan fisik yang prima. Hal ini diperlukan karena biasanya pagelaran wayang kulit itu dilaksanakan semalam suntuk. Tentu harus mempunyai fisik yang sehat dan kuat untuk melantunkan lagu-lagu jawa serta menahan kantuk mulai senja hingga pagi hari.

Semua unsur tersebut dipimpin dan digerakkan oleh seorang Dalang sehingga bisa menjadi pertunjukan yang menarik. Pertunjukan wayang membutuhkan semuah hal tersebut sehingga untuk setiap pementasan wayang kulit memerlukan biaya yang cukup besar.

Masing-masing dalang mempunyai ciri-ciri tersendiri dalam memainkan wayang dan memimpin pertunjukan pagelaran wayang dan hal tersebut menjadi pembeda dalam setiap pertunjukan yang dilakukannya. 


\section{Hak Ekonomi Dalang Dalam Pertunjukan Wayang Kulit}

Dalang sebagai pelaku utama dari sebuah pertunjukan wayang kulit memiliki hak yang diatur dalam Undang-Undang Hak Cipta yaitu hak terkait. Hak terkait adalah hak yang berkaitan dengan Hak Cipta yang merupakan hak ekslusif bagi pelaku pertunjukan, producer fonofram, atau lembaga penyiaran (Pasal 1 ayat (4)). Hak terkait memberikan hak kepada Dalan untuk dapat melaksanakan sendiri, memberikan izin, atau melarang pihak lain untuk melakukan: (Pasal 23 ayat 2)

a. Penyiaran atau Komunikasi atas pertunjukan Pelaku Pertunjukan;

b. Fiksasi dari pertunjukannya yang berlum difiksasi;

c. Penggandaan atas Fiksasi pertunjukannya dengan cara atau bentuk apapun

d. Pendistribusian atas Fiksasi pertunjukan atau salinannya

e. Penyewaan atas fiksasi pertunjukan atau salinannya kepada publik; dan

f. Penyediaan atas Fiksasi pertunjukan yang dapat diakses publik

Untuk mendapatkan haknya tersebut tentu Dalang dapat memberikan kuasa kepada pihak lain untuk mengawasi pihak yang mempergunakan hak terkait yang dimilikinya dan meminta serta mengumpulkan royalti atas pengunaan hak terkait tersebut. Pihak yang dapat diberikan kuasa oleh Dalang untuk mendapatkan haknya tersebut adalah Lembaga Manajemen Kolektif Nasional.

Lembaga Manajemen Kolektif Nasional merupakan Lembaga yang diamanatkan oleh Undang-undang Hak Cipta yang baru, yaitu Undang-undang No. 28 Tahun 2014 (selanjutnya disebut UUHC 2014). Undang-undang No. 28 Tahun 2014 tentang Hak Cipta disebutkan bahwa Lembaga Manajemen Kolektif adalah institusi yang berbentuk badan hukum nirlaba yang diberi kuasa oleh Pencipta, Pemegang Hak Cipta, dan/atau pemilik Hak Terkait guna mengelola hak ekonominya dalam bentuk menghimpun dan mendistribusikan royalty.

Bahwa ketentuan tentang Lembaga Manajamen Kolektif disebutkan didalam UUHC 2014 diterangkan bahwa: "Untuk mendapatkan hak ekonomi setiap Pencipta, Pemegang Hak Cipta, pemilik Hak Terkait menjadi anggota Lembaga Manajemen Kolektif agar dapat menarik imbalan yang wajar dari pengguna yang memanfaatkan Hak Cipta dan Hak Terkait dalam bentuk layanan publik yang bersifat komersial". Dan Pengguna Hak Cipta dan Hak Terkait yang memanfaatkan Hak harus membayar Royalti kepada Pencipta, Pemegang Hak Cipta, atau pemilik Hak Terkait, melalui Lembaga Manajemen Kolektif. Sebenarnya bagaimanakah prosedur untuk mendirikan Lembaga Manajemen Kolektif menurut UUHC 2014. Bahwa menurut ketentuan UUHC 2014 diterangkan bahwa Izin operasional Lembaga Manajemen Kolektif harus memenuhi syarat:

a. berbentuk badan hukum Indonesia yang bersifat nirlaba; 
b. mendapat kuasa dari Pencipta, Pemegang Hak Cipta, atau pemilik Hak Terkait untuk menarik, menghimpun, dan mendistribusikan Royalti;

c. memiliki pemberi kuasa sebagai anggota paling sedikit 200 (dua ratus) orang Pencipta untuk Lembaga Manajemen Kolektif bidang lagu dan/atau musik yang mewakili kepentingan pencipta dan paling sedikit 50 (lima puluh) orang untuk Lembaga Manajemen Kolektif yang mewakili pemilik Hak Terkait dan/atau objek Hak Cipta lainnya;

d. bertujuan untuk menarik, menghimpun, dan mendistribusikan Royalti; dan

e. mampu menarik, menghimpun, dan mendistribusikan Royalti kepada Pencipta, Pemegang Hak Cipta, atau pemilik Hak Terkait.

Royalty menurut UUHC 2014 adalah imbalan atas pemanfaatan Hak Ekonomi suatu Ciptaan atau Produk Hak Terkait yang diterima oleh pencipta atau pemilik hak terkait. Sedangkan Lisensi adalah izin tertulis yang diberikan oleh Pemegang Hak Cipta atau Pemilik Hak Terkait kepada pihak lain untuk melaksanakan hak ekonomi atas Ciptaannya atau produk Hak Terkait dengan syarat tertentu.

Dan sebagaimana diketahui bersama di Indonesia memang sudah ada Lembaga Manajemen Kolektif sebagai lembaga yang bertugas untuk menghimpun dan mendistribusikan royalty dari pencipta, pemegang hak cipta dan atau pemilik hak terkait, Lembaga Manajemen Kolektif yang sekarang sudah ada diantaranya adalah YKCI, WAMI dan Lembaga Manajemen Kolektif (selanjutnya disebut LMK) lainnya yang secara Legal sudah terdaftar dan mewakili kepentingan pencipta, pemegang hak cipta dan atau pemilik hak terkait. Lembaga Manajemen Kolektif merupakan kepanjangan tangan dari Pencipta, Pemegang Hak Cipta, pemilik Hak Terkait untuk menarik imbalan yang wajar dari pengguna yang memanfaatkan Hak Cipta dan Hak Terkait dalam bentuk layanan publik yang bersifat komersial, sehingga mereka mendapatkan pemanfaatan ekonomi terhadap karya cipta mereka yang digunakan dan dimanfaatkan secara komersiil.

Bahwa UUHC 2014 didalam Pasal 10 disebutkan bahwa; Pengelola tempat perdagangan dilarang membiarkan penjualan dan/atau penggandaan barang hasil pelanggaran Hak Cipta dan/atau Hak Terkait di tempat perdagangan yang dikelolanya. Ketentuan Pasal 10 dimaksudkan bahwa setiap pusat perdagangan baik itu dalam skala kecil maupun besar (mall) harus bisa mengontrol dan mencegah setiap jenis usaha yang ada didalamnya yang menggunakan atau memanfaatkan hak-hak yang terdapat didalam hak cipta yang pemanfaatannya secara komersiil harus tunduk terhadap ketentuan UUHC 2014. Kepatuhan untuk tertib didalam ketentuan UUHC 2014 tersebut

\footnotetext{
5 http://dimaspratama11.wordpress.com/2011/11/19/analisis-upaya-melestarikan-budaya-bangsa/, diakses tanggal 10 Desember 2015.
} 
diharapkan bisa melindungi pencipta dan pemilik hak terkait serta pemegang hak cipta dari tindakan-tindakan pemanfaatan atas hak-hak mereka secara tidak benar (tidak mendapatkan izin). Dan ketentuan Pasal 10 ini juga menekankan bahwa bahwa setiap tempat usaha yang berada dilingkup tempat perdagangan, misalnya restoran, cafe, dan usaha lainnya yang sejenis yang memanfaatkan hak cipta dalam bentuk hak terkait untuk kepentingan komersiilnya, harus benar-benar sudah sesuai dengan ketentuan UUHC 2014.

Lembaga Manajemen Kolektif yang ada saat ini baru ada untuk karya cipta yang berbenuk lagu sehingga perlu dibentuk Lembaga Manajemen Kolektif yang menjadi kepanjangan tangan dari Dalang untuk memperoleh haknya.

Memang diakui bila saat ini stasiun televisi dan tempat-tempat hiburan yang menayangkan pertunjukan wayang kulit masih jarang sehingga belum ada yang membentuk lembaga tersebut. Peran pemerintah dalam hal ini sangat diperlukan untuk mendorong disiarkannya penayangan wayang kulit di setasiun-setasiun televisi baik stasiun televisi pemerintah maupun swasta.

Pemerintah dapat menjadi motor bagi gerakan mencintai budaya wayang kulit dengan menyediakan sarana dan prasarana yang diperlukan Dalang untuk melakukan pertunjukan seperti tempat pertunjukan, menyelengarakan acaraacara pemerintah dengan hiburan wayang kulit serta memberikan insentif kepada Dalang untuk melakukan pertunjukan.

\section{Wayang Kulit sebagai Ekpresi Budaya Tradisional ${ }^{6}$}

Pengertian ekspresi budaya tradisional adalah segala bentuk ekspresi, baik material (benda) maupun immaterial (tak benda), atau kombinasi keduanya yang menunjukkan keberadaan suatu budaya dan pengetahuan tradisional yang menunjukkan keberadaan suatu budaya dan pengetahuan tradisional yang bersifat turu-temurun. Wayang kulit berdasarkan pengertian tersebut termasuk ekspresi budaya tradisional yang dimiliki olen negara Indonesia sedangkan kelompok masyarakat yang telalh memelihara, mengembangkan, memanfaatkan, atau melestarikannya disebut sebagai insan budaya.

Dalam hal pengembangan wayang kulit sebagai ekspresi budaya tradisional pemerintah mempunyai wewenang untuk :

a. menetapkan kebijakan nasional tentang Pengetahuan Tradisional dan Ekspresi Budaya Tradisional;

b. mengoordinasikan dan melaksanakan pengembangan Pengetahuan Tradisional dan Ekspresi Budaya Tradisional; dan

\footnotetext{
${ }^{6}$ Rancangan Undang-Undang Republik Indonesia tentang Pengetahuan Tradisional dan Ekspresi Budaya Tradisional.
} 
c. memfasilitasi dan memperkuat para Insan Budaya dan masyarakat dalam pengembangan Pengetahuan Tradisional dan Ekspresi Budaya Tradisional.

Pihak yang ingin memanfaatan wayang kulit seagai ekpresi budaya tradisional dapat dilakukan dengan tujuan komersial dan non komersial. Pemanfaatan secara komersial dapat diukur berdasarkan skala ekonomi tertentu berdasarkan:

a. komponen minimal tingkat keuntungan;

b. tingkat inflasi;

c. tingkat daya beli masyarakat;

d. keberadaan Hak Kekayaan Intelektual.

Pemanfaatan wayang kulut sebagai Pengetahuan Tradisional dan Ekspresi Budaya Tradisional dengan tujuan nonkomersial terdiri atas:

a. penelitian dalam rangka perlindungan dan pelestarian pengetahuan Tradisional dan ekspresi budaya tradisional;

b. penelitian dalam rangka tujuan pendidikan;

c. pemanfaatan secara tradisional oleh anggota masyarakat yang bersangkutan.

Pembagian manfaat ekonomi dari wayang kulit dilakukan untuk:

a. mengembangkan pengetahuan tentang wayang kulit tersebut;

b. membuka peluang bagi masyarakat dalam memperoleh manfaat ekonomi dari wayang kulit sebagai ekspresi budaya tradisional.

Berdasarkan ketentuan PTEBT Pemerintah, Pemeritah Daerah, atau Pengguga wajib melakukan upaya Pelestarian Pengetahuan Tradisional dan Ekspresi Budaya Tradisional dengan menggunakan berbagai sumber daya, sarana, dan prasarana secara aktif. Pelestarian tersebut mencakup kegiatan inventarisasi, identifikasi, dokumentasi, penelitian, revitalisasi, dan Promosi, baik dengan menggunakan perangkat modern maupun dengan cara tradisional, termasuk melalui pendidikan formal dan nonformal.

Selain kewajiban untuk melestarikan, pemerintah juga punya kewajiban untuk melindungi wayang kulit sebagai ekspresi budaya tradisional dan langkah-langkahnya meliputi pengawasan, pembinaan, gugatan perdata, pencabutan izin, atau penuntutan pidana.

\section{Perlindungan Wayang Kulit}

Wayang kulit sebagai peningalan budaya sangat rentan untuk musnah apabila tidak ada upaya yang sungguh-sungguh untuk melestarikannya baik 
oleh pemerintah maupun oleh masyarakat. Wayang kulit sebagai kebudayaan dapat dilestarikan dalam dua bentuk yaitu: ${ }^{7}$

\section{Culture Experience}

Merupakan pelestarian budaya yang dilakukan dengan cara terjun langsung kedalam sebuah pengalaman kultural. contohnya, jika kebudayaan tersebut berbentuk tarian, maka masyarakat dianjurkan untuk belajar dan berlatih dalam menguasai tarian tersebut. Dengan demikian dalam setiap tahunnya selalu dapat dijaga kelestarian budaya kita ini.

\section{Culture Knowledge}

Merupakan pelestarian budaya yang dilakukan dengan cara membuat suatu pusat informasi mengenai kebudayaan yang dapat difungsionalisasi kedalam banyak bentuk. Tujuannya adalah untuk edukasi ataupun untuk kepentingan pengembangan kebudayaan itu sendiri dan potensi kepariwisataan daerah. Dengan demikian para Generasi Muda dapat mengetahui tentang kebudayaanya sendiri.

Selain dilestarikan dalam dua bentuk diatas, wayang kulit juga dapat dilestarikan dengan cara mengenal budaya wayang kulit itu sendiri. Dengan hal ini setidaknya kita dapat mengantisipasi pencurian kebudayaan yang dilakukan oleh negara-negara lain. Penyakit masyarakat kita adalah mereka terkadang tidak bangga terhadap produk atau kebudayaannya sendiri. Kita lebih bangga terhadap budaya-budaya impor yang sebenarnya tidak sesuai dengan budaya kita sebagai orang timur. Budaya daerah banyak hilang dikikis zaman. Oleh sebab kita sendiri yang tidak mau mempelajari dan melestarikannya. Akibatnya kita baru bersuara ketika negara lain sukses dan terkenal dengan budaya yang mereka curi secara diam-diam.

Selain itu peran pemerintah dalam melestarikan budaya wayang kulit juga sangatlah penting. Bagaimanapun pemerintah memiliki peran yang cukup strategis dalam upaya pelestarian kebudayaan daerah ditanah air. Pemerintah harus mengimplementasikan kebijakan-kebijakan yang mengarah pada upaya pelestarian kebudayaan nasional. Pemerintah dapat mengeluarkan kebijakan untuk menampilkan wayang kulit pada setiap event-event akbar nasiona. Hal tersebut harus dilakukan sebagai upaya pengenalan kepada generasi muda, bahwa wayang kulit yang ditampilkan itu adalah warisan dari leluhurnya dan bukan berasal dari negara tetangga. Demikian juga upaya-upaya melalui jalur formal pendidikan. Masyarakat harus memahami dan mengetahui berbagai kebudayaan wayang kulit yang kita miliki.

\footnotetext{
${ }^{7}$ https://puthutnugroho.wordpress.com/2014/08/26/unsur-unsur-dalam-pertunjukan-wayang-kulitpurwa/, diakses pada tanggal 10 Desember 2015.
} 
Selain langkah tersebut yang terpenting adalah memperhatikan kesejahteraan dari pelaku wayang kulit. Seniman yang menjalani profesi wayang kulit harus diperhatikan kesejahtaraanya, peningkatan kesejahtaraan akan mendorong pelaku seni wayang untuk merasa tenang dalam menjalani prosfesinya. Cara memperhatikan kesejahtaraan juga dapat ditempuh dengan cara mengangkat setiap Dalang yang mengisi pementasan wayang kulit secara rutin di Stasiun radio atau televisi pemerintah sebagai pegawai Pemerintah Daerah

Perhatian pemerintah kepada pelaku seni juga dapat diberikan dalam bentuk menyediakan tempat untuk menyelengarakan pementasan wayang kulit. Sebagaimaan diuraikan dimuka bahwa pementasan wayang kulit hanya dilakukan apabila ada yang mengundang sehingga pementasannya tidak bisa dilakukan secara rutin. Adanya tempat untuk pementasan wayang kulit memungkinkan pementasan dapat dilakukan secara terjadwal sehingga para Dalang dapat bergantian melakukan pementasan.

Peran pemerintah dalam memajukan budaya wayang kulit dapat dilakukan dengan membantu promosi terhadap kegiatan pementasan wayang kulit, juga perlu dilakukan, promosi tersebut dilakukan ke sekolah-sekolah. Sekolah dapat membuat sebuah kegiatan ekstrakulikuler yang mewajibkan siswanya untuk melihat pertunjukan wayang kulit dan mebuat laporan atas tugas tersebut. 


\section{Daftar Pustaka}

Undang-Undang Nomor 28 Tahun 2014 tentang Hak Cipta.

Rancangan Undang-Undang Republik Indonesia tentang Pengetahuan Tradisional dan Ekspresi Budaya Tradisional.

Arifin, Ferdi. Wayang Kulit sebagai media pendidikan Budi Pekerti, "Jurnal Sejarah dan Budaya (Jantra)", Vol. 8, No. 1, Juni 2013: 75.

Amir, H. Nilai-Nilai Etis Dalam Wayang, Jakarta: Pustaka Sinar Harapan, 1991.

Guritno, P. Wayang, Kebudayaan Indonesia dan Pancasila. Jakarta: Universitas Indonesia Press, 1988.

Hasrinuksmo B. Ensiklopedi Wayang Indonesia. Jakarta: Sena Wangi, 1999.

Isma'un, B. Peranan Koleksi Wayang dalam Kehidupan Masyarakat. Yogyakarta: Depdikbud, 1990.

Soedarsono. Beberapa Catatan Tentang Seni Pertunjukan Indonesia. Yogyakarta: Konservatori Tari Indonesia di Yogyakarta, 1970.

Walujo K. Dunia wayang. Yogyakarta: Pustaka Pelajar, 2000.

https://puthutnugroho.wordpress.com/2014/08/26/unsur-unsur-dalampertunjukan-wayang-kulit-purwa/,

anonim. 2008. Perlindungan warisan budaya. http://www.bpsnt-makassar.net/ index.php/artikel-bpsnt/publikasi/91-sosialisasi-perlindungan-warisanbudaya-intangible.html

anonom. 2009. Makalah perubahan kebudayaan karena dari luar. http://isbdti.blog.uns.ac.id/2009/11/09/makalah-perubahan-kebudayaankarena-pengaruh-dari luar/

http://dimaspratama11.wordpress.com/2011/11/19/analisis-upayamelestarikan-budaya-bangsa/ 